\title{
$\begin{array}{ll}\text { Research Square } & \begin{array}{l}\text { Preprints are preliminary reports that have not undergone peer review. } \\ \text { They should not be considered conclusive, used to inform clinical practice, } \\ \text { or referenced by the media as validated information. }\end{array}\end{array}$
}

\section{Morphological and Molecular Characteristics of Fungal Species Associated with Crown Rot of Strawberry in South Korea}

\author{
Oliul Hassan \\ Kyungpook National University \\ Taehyun Chang ( $\nabla$ thchang@knu.ac.kr) \\ Kyungpook National University https://orcid.org/0000-0002-0213-7444
}

\section{Research Article}

Keywords: morphology, multilocus phylogeny, root rot, strawberry

Posted Date: July 30th, 2021

DOI: https://doi.org/10.21203/rs.3.rs-713894/v1

License: (9) (1) This work is licensed under a Creative Commons Attribution 4.0 International License. Read Full License

Version of Record: A version of this preprint was published at Molecular Biology Reports on November 3rd, 2021. See the published version at https://doi.org/10.1007/s11033-021-06841-9. 


\section{Abstract}

Crown and root rot is the most important and destructive strawberry diseases in Korea as it causessubstantial economic loss. In August 2020, a severe outbreak of crown and root rot on strawberries (Fragariaxananassa Duch.) was observed in the greenhouse at Sangju, South Korea. Infected plantlets displayed browning rot within the crown and root, stunted growth, and poor rooting. Thirty fungal isolates were procured from the affected plantlet. Isolates were identified based on morphological characteristics and pathogenicity test as well as sequence data obtained from internal transcribed spacer, large subunit ribosomal ribonucleic acid, translation elongation factor,and RNA polymerase $₫$-second largest subunit. Results showed that thecrown and root rot of strawberry in Korea was caused by three distinct fungal species:Fusarium oxysporum species complex, F. solani species complex, andPlectosphaerella cucumerina. To the best of our knowledge, $F$. solani species complex and $P$. cucumerinaare reported for the first time as the causal agents of the crown and root rot of strawberryin South Korea.Pathogenicity tests confirmed that these isolates are pathogenic to strawberry. Understanding the composition and biology of the pathogen population will be helpful toprovide effectivecontrol strategies for the disease.

\section{Introduction}

Strawberry (Fragaria $\times$ ananassa) is cultivated across South Korea. South Korean strawberry is the most popular fruit due to its softness and sweetness. In South Korea, the cultivation of this fruit has increased rapidly in recent years. The cultivation area occupies 6435 hectares, and the total production is 208,699 tons (Wei et al., 2020). With the expansion of growing areas and increase in output, many fungal diseases are posing a challenge to strawberry growers in South Korea. Among them, the crown and root rot in strawberry is the most important and destructive disease. It is also a common threat to commercial production of strawberry worldwide, including Australia, Bangladesh, and China (Fang et al., 2012; Gilardi et al., 2019; Surovy et al., 2019; Zhan et al., 2020). This disease limits plant growth and fruit production (Fang et al., 2012; Gilardi et al., 2019). The browning rot within the crown and root, stunted growth, and poor rooting are the typical manifestations in an infected plant (Park et al., 2019). Single or combinations of fungal and oomycete pathogens are responsible for this strawberry disease (Fang et al., 2012). Fusarium oxysporum and Rhizoctonia spp. are the frequently reported fungal species that cause crown and root rot of strawberry (Fang et al., 2011; Fang et al., 2012). Thus far, in South Korea, Fusarium oxysporum f. sp. fragariae, Pythium spp. $R$. fragariae, $R$. solani, and Neopestalotiopsis clavispora have been reported as the so-called crown and root rot of strawberry (KSPP 2009; Nam et al., 2020; Gilardi et al., 2019).

The causative agents of crown and root rot of strawberry were identified using the most traditional method (KSPP 2009; Gilardi et al,. 2019). The shape and size of the conidia and chlamydospores and culture characteristics were used in the conventional method. These criteria are not enough to delineate fungal species, especially species within the Fusarium oxysporum complex due to the following reasons: the fungal species complex share similar features and environmental factors that influence morphological characteristics (Taylor et al., 2000; Stewart et al., 2006). Molecular analysis along with morphological characteristics is a highly recommended approach for the precious identification of fungal species. Nam et al. (2020) described the genetic diversity of $F$. oxysporum $\mathrm{f}$. sp. fragariae from strawberry in Korea using the nuclear ribosomal intergenic spacer region and translation elongation factor $(E F-I a)$ gene. They found that all the isolates of $F$. oxysporum f. sp. fragariae were formed of three clades in the phylogenetic tree. EF-la is an essential molecular marker that identifies most but not all fusaria (Geiser et al., 2004). O'Donnell et al., (2015) suggested DNA sequence-based identification of Fusarium using TEF-1, RNA polymerase II largest (RPB1), and the second largest subunit (RPB2) marker. Fusariam spp. needs to be identified using the recommended new gene marker.

According to the most of the grower from the Sangju region of South Korea, crown and root rot of strawberry has become more destructive and prevalent recently. The pathogens responsible for this disease in Sangju, Korea, have not been systematically investigated. Anxiety among the farmers is growing as the management strategies that were taken to contain this disease were not effective. One of the main reasons behind this could be the lack of proper diagnosis of the pathogen population. The sensitivity of fungi in different genera or different species within the same genus against a particular fungicide is not the same (Hellin et al. 2017; Ramdial et al. 2017). Hellin et al. (2017) found that $F$. culmorum is more sensitive to triazoles compared with F. graminearum and F. cerealis. Cholletotrichum truncatum isolated from bell paper is less susceptible to benomyl fungicide compared with $F$. incarnatum-equiseti species complex isolates (Ramdial et al., 2017). The identification of the pathogen population is essential to develop control strategies especially using fungicides.

This study aimed to identify the potential pathogens associated with the crown and root rot of strawberry in Sangju, Korea, characterized using a morphological and multigene approach. Moreover, this study aimed to confirm the pathogenicity of any recovered isolates.

\section{Materials And Methods}




\section{Sample collection, pathogen isolation, and primary identification of pathogen population}

Twenty-five affected strawberry plants showing wilting, collapse and root and crown rot were sampled from five greenhouses in Sangju, South Korea (Fig. 1). Crown was the more affected part compared with the root in these plants. The plants were propagated using the runner pegging method in a pot containing pasteurized soil and vermicompost. Plants were drip-irrigated with fertilizer mixed river water to adjust nutrients in the pot soil. Approximately $6 \mathrm{~mm}^{2}$ tissue pieces were cut from the discolored area of the crown (Fig. 1D) of sampled plant, surface sterilized by dipping into $0.5 \% \mathrm{NaOCl}$ solution for $1 \mathrm{~min}$ followed by $40 \mathrm{~s}$ in $70 \%$ ethanol, rinsed twice in sterile water, and then blot-dried with clean tissue paper. Tissue pieces plated on potato dextrose agar (PDA; Difco Becton Dickinson) were amended with $0.05 \mathrm{~g} / \mathrm{L}$ tetracycline and incubated at room temperature $\left(23^{\circ} \mathrm{C} \pm 2^{\circ} \mathrm{C}\right)$ in the dark for $2-3 \mathrm{~d}$. Hyphal tips of emerging hyphae were transferred to fresh PDA and were cultured for further use. A total of 30 pure fungal isolates were obtained and identified to genus level using morphological characteristics (Šišić et al.2018; Maryani et al. 2019; Zhang et al. 2019). For a long time, all the isolates were preserved as mycelium in $10 \%$ glycerin at $-70^{\circ} \mathrm{C}$. Then, pure culture repregenting identified each fungal species were deposited in the Korean Agricultural Culture Collection (KACC). (note: accession number will be assaign soon).

\section{DNA extraction, PCR amplification, and sequencing}

The fungal isolates from the strawberry plant were tentatively identified as Fusarium spp. and Plectosphaerella spp. based morphological criteria (Šišić et al., 2018; Maryani et al., 2019; Zhang et al., 2019). All the isolates of Plectosphaerella spp. shared the similar colony color, whereas some isolates of Fusarium spp. were pinkish-white and some were white. Four isolates Plectosphaerella spp. and nine isolates from Fusarium spp. (six pinkish-white and three white) were selected for species identification using the molecular approach. Actively growing cultures on PDA were used for DNA isolation. Genomic DNA was isolated using The HiGene Genomic DNA Prep Kit (BIOFACT, Yuseong-Gu, and Daejeon, Korea) following the instruction of the manufacturer and then stored at $4^{\circ} \mathrm{C}$ for further use.

Following four genes were selected for amplification and sequencing: the internal transcribed spacer (ITS) region and domains D1/D2/ D3 of the nuclear large subunit ( $L S U$ ) rRNA, the translation elongation factor 1 alpha ( $E F-1 a$ ), and the second largest subunit ( $r p b 2)$. The selected genetic fragments (ITS, LSU, EF-1 $a$, and rpb2) were amplified with the primers listed in Table 1 using the PCRmax Alpha cyclers (PCR max, Stone, United Kingdom) in a total volume of $25 \mathrm{uL}$. The PCR mixture contained $2.5 \mu \mathrm{L}$ F-star buffer, $0.5 \mu \mathrm{L}$ dNTP Mix (each $10 \mathrm{mM}), 1 \mu \mathrm{L}$ forward primer ( $10 \mathrm{pmol}), 1 \mu \mathrm{L}$ reverse primer (10 pmol), $1 \mu \mathrm{L}$ template DNA, $0.2 \mu \mathrm{L}$ F-star (Taq DNA polymerase), and $18.8 \mu \mathrm{L}$ Invitrogen ultrapure DNase/RNase free distilled water. The PCR conditions for $I T S$ were as follows: 4 min at $95^{\circ} \mathrm{C}, 30 \mathrm{~s}$ at $95^{\circ} \mathrm{C}, 30 \mathrm{~s}$ at $55^{\circ} \mathrm{C}$ (annealing), $45 \mathrm{~s}$ at $72^{\circ} \mathrm{C}(34 \mathrm{cycles})$, and a final extension of $7 \mathrm{~min}$ at $72^{\circ} \mathrm{C}$. The PCR conditions for $\angle S U, E F-1 a$, and $r p b 2$ were almost similar to that of ITS except for the annealing temperature. The annealing temperature for $\angle S U, E F-1 a$, and $r p b 2$ were $60^{\circ} \mathrm{C}, 56^{\circ} \mathrm{C}$, and $59^{\circ} \mathrm{C}$, respectively. To confirm successful PCR reactions, all resulting PCR products were visualized in $1.5 \%$ agarose gels (wt/v) stained with ethidium bromide and viewed under ultra-violet light. The products of the confirmed PCR reaction were purified using a HiGene PCR Purification Kit (Yuseong-Gu) as instructed by the manufacturer and sequenced in both directions directly with the help of Macrogen, Inc (Seoul, Korea). The resulting sequences were analyzed in SeqMan v.7.1 from the Lasergene package (DNASTAR, Inc.Madison, WI 53705 USA), edited manually whenever necessary, saved as a consensus sequence, and then deposited in the GenBank. The accession numbers of present and reference isolates are given in Table 2. 
Table 1

List of primer sets used for amplification of selected genetic fragments.

\begin{tabular}{|lllll|}
\hline Gene & Primer Name & Direction & Sequence (5'-3') & References \\
\hline ITS & ITS-1 & Forward & TCCGTAGGTGAACCTGCGG & White et al. (1990) \\
\cline { 2 - 5 } & ITS-4 & Reverse & TCC TCC GCT TAT TGA TAT GC & White et al. (1990) \\
\hline LSU & LROR & Forward & ACCCGCTGAACTTAAGC & $\begin{array}{l}\text { Rehner and } \\
\end{array}$ \\
\cline { 2 - 5 } & LR5 & Reverse & TCCTGAGGGAAACTTCG & Vilgalys and Hester 1990 \\
\hline EF-1 a & EF1 & Forward & ATGGGTAAGGARGACAAGAC & O'Donnell et al. (1998) \\
\cline { 2 - 5 } & EF2 & Reverse & GGARGTACCAGTSATCATG & O'Donnell et al. (1998) \\
\hline rpb1 & RPB1-Fa & Forward & CAYAARGARTCYATGATGGGWC & O'Donnell et al. (2010) \\
\cline { 2 - 5 } & RPB1-G2R & Reverse & GTCATYTGDGTDGCDGGYTCDCC & O'Donnell et al. (2010) \\
\hline rpb2 & RPB2-5F2 & Forward & GGGGWGAYCAGAAGAAGGC & O'Donnell et al. (2010) \\
\cline { 2 - 5 } & RPB2-7cR & Reverse & CCCATRGCTTGYTTRCCCAT & O'Donnell et al. (2010) \\
\cline { 2 - 5 }
\end{tabular}


Table 2

GenBank accession numbers of fungal isolates used in this study.

\begin{tabular}{|c|c|c|c|c|c|c|c|}
\hline \multirow[t]{2}{*}{ Species } & \multirow[t]{2}{*}{ Isolates } & \multirow[t]{2}{*}{ Origin } & \multirow[t]{2}{*}{ Host } & \multicolumn{4}{|c|}{ GenBank accession number } \\
\hline & & & & ITS & $E F-1 a$ & rpb2 & LSU \\
\hline F. incarnatum-equiseti & NRRL45997 & - & - & & GQ505672 & GQ505850 & \\
\hline F. longipes & NRRL20695 & - & & & GQ915509 & GQ915493 & \\
\hline F. mangiferae & UMAF 0924 & - & $\begin{array}{l}\text { Mangifera } \\
\text { indica }\end{array}$ & & KP753402 & KP753442 & \\
\hline $\begin{array}{l}\text { F. oxysporum f. } \\
\text { sp.conglutinans }\end{array}$ & NRRL54008 & $\begin{array}{l}\text { Raphanus } \\
\text { sp. }\end{array}$ & - & & LS479673 & LS479225 & \\
\hline $\begin{array}{l}\text { F. oxysporum f. } \\
\text { sp.cubense }\end{array}$ & FocCNPMF-R1 & Brazil & & & LS479642 & LS479196 & \\
\hline \multirow[t]{2}{*}{$\begin{array}{l}\text { F. oxysporum f. } \\
\text { sp.lycopersici }\end{array}$} & NRRL34936 & & $\begin{array}{l}\text { Solanum } \\
\text { lycopersicum }\end{array}$ & & LS479646 & LS479200 & \\
\hline & NRRL 26381 & & $\begin{array}{l}\text { S. } \\
\text { lycopersicum }\end{array}$ & & LS479641 & LS479195 & \\
\hline \multirow[t]{6}{*}{$\begin{array}{l}\text { F. oxysporum (present } \\
\text { isolates) }\end{array}$} & SJB143 & $\begin{array}{l}\text { South } \\
\text { Korea }\end{array}$ & $\begin{array}{l}\text { Fragaria x } \\
\text { ananassa }\end{array}$ & LC633891 & LC633917 & LC633930 & LC633904 \\
\hline & SJB232 & $\begin{array}{l}\text { South } \\
\text { Korea }\end{array}$ & $\begin{array}{l}\text { Fragaria x } \\
\text { ananassa }\end{array}$ & LC633892 & LC633918 & LC633931 & LC633905 \\
\hline & SJB382 & $\begin{array}{l}\text { South } \\
\text { Korea }\end{array}$ & $\begin{array}{l}\text { Fragaria x } \\
\text { ananassa }\end{array}$ & LC633893 & LC633919 & LC633932 & LC633906 \\
\hline & SJB593 & $\begin{array}{l}\text { South } \\
\text { Korea }\end{array}$ & $\begin{array}{l}\text { Fragaria x } \\
\text { ananassa }\end{array}$ & LC633894 & LC633920 & LC633933 & LC633907 \\
\hline & SJB522 & $\begin{array}{l}\text { South } \\
\text { Korea }\end{array}$ & $\begin{array}{l}\text { Fragaria x } \\
\text { ananassa }\end{array}$ & LC633895 & LC633921 & LC633934 & LC633908 \\
\hline & SJB462 & $\begin{array}{l}\text { South } \\
\text { Korea }\end{array}$ & $\begin{array}{l}\text { Fragaria x } \\
\text { ananassa }\end{array}$ & LC633896 & LC633922 & LC633935 & LC633909 \\
\hline $\begin{array}{l}\text { F. oxysporum f. sp. } \\
\text { melonis }\end{array}$ & NRRL26406 & & $\begin{array}{l}\text { Cucumis } \\
\text { melo }\end{array}$ & & LS479647 & LS479201 & \\
\hline F. oxysporum f. sp.pisi & NRRL37622 & & Cicersp. & & LS479649 & LS479203 & \\
\hline $\begin{array}{l}\text { F. oxysporum f. } \\
\text { sp.raphani }\end{array}$ & NRRL54005 & & & & LS479649 & LS479203 & \\
\hline F. proliferatum & NRRL62905 & & & & KU171727 & KU171707 & \\
\hline F. solani & NRRL32810 & USA & & DQ094577 & DQ247118 & EU329624 & \\
\hline \multirow[t]{3}{*}{ F. solani (present isolates) } & SJB62 & $\begin{array}{l}\text { South } \\
\text { Korea }\end{array}$ & $\begin{array}{l}\text { Fragaria x } \\
\text { ananassa }\end{array}$ & LC633897 & LC633923 & LC633936 & LC633910 \\
\hline & SJB222 & $\begin{array}{l}\text { South } \\
\text { Korea }\end{array}$ & $\begin{array}{l}\text { Fragaria x } \\
\text { ananassa }\end{array}$ & LC633898 & LC633924 & LC633937 & LC633911 \\
\hline & SJB243 & $\begin{array}{l}\text { South } \\
\text { Korea }\end{array}$ & $\begin{array}{l}\text { Fragaria x } \\
\text { ananassa }\end{array}$ & LC633899 & LC633925 & LC633938 & LC633912 \\
\hline F. solanif. sp. batatas & NRRL22400 & USA & $\begin{array}{l}\text { Ipomoea } \\
\text { batatas }\end{array}$ & DQ094303 & AF178343 & EU329509 & \\
\hline F. solani f. sp. cucurbltae & NRRL22153 & & Cucurbitae & DQ094302 & AF178346 & EU329492 & \\
\hline F. solanif. sp. mori & NRRL22157 & Japan & Morus alba & DQ094306 & AF178359 & EU329493 & \\
\hline F. solanif.s p. robiniae & NRRL22161 & Japan & $\begin{array}{l}\text { Musa } \\
\text { rubinea }\end{array}$ & DQ094311 & AF178330 & EU329494 & \\
\hline F. solanif. sp. xanthoxyli & NRRL22163 & & & AF178394 & AF178328 & EU329496 & \\
\hline
\end{tabular}




\begin{tabular}{|c|c|c|c|c|c|c|c|}
\hline \multirow[t]{2}{*}{ Species } & \multirow[t]{2}{*}{ Isolates } & \multirow[t]{2}{*}{ Origin } & \multirow[t]{2}{*}{ Host } & \multicolumn{4}{|c|}{ GenBank accession number } \\
\hline & & & & ITS & $E F-1 a$ & $\mathrm{rpb} 2$ & LSU \\
\hline Fusarium sp.(FSSC24a) & NRRL32751 & USA & & DQ094531 & DQ247070 & EU329611 & \\
\hline Fusarium sp. (FSSC34) & NRRL46703 & & & EU329712 & HM347126 & EU329661 & \\
\hline Fusarium sp. (FSSC9a) & NRRL32755 & USA & & DQ094534 & DQ247073 & EU329613 & \\
\hline Fusarium sp. (FSSC8) & NRRL43467 & USA & & EF453092 & EF452940 & EF469979 & \\
\hline Plectosphaerella alismatis & CBS 113362 & Netherland & & LR026794 & LR026489 & LR026196 & LR025932 \\
\hline P. citrullae & CBS 131741 & Netherland & & LR026796 & LR026491 & LR026197 & LR025934 \\
\hline \multirow[t]{4}{*}{ P. cucumerina } & CBS 137.33 & Netherland & & LR026797 & LR026492 & LR026198 & LR025935 \\
\hline & CBS 139.60 & Netherland & & LR026799 & LR026494 & LR026200 & LR025937 \\
\hline & CBS 137.37 & Netherland & & LR026798 & LR026493 & LR026199 & LR025936 \\
\hline & CBS 286.64 & Netherland & & LR026800 & LR026495 & LR026201 & LR025938 \\
\hline \multirow{4}{*}{$\begin{array}{l}\text { P. cucumerina } \\
\text { (present isolates) }\end{array}$} & SJB163 & $\begin{array}{l}\text { South } \\
\text { Korea }\end{array}$ & $\begin{array}{l}\text { Fragaria } \mathrm{x} \\
\text { ananassa }\end{array}$ & LC633900 & LC633926 & LC633939 & LC6339103 \\
\hline & SJB183 & $\begin{array}{l}\text { South } \\
\text { Korea }\end{array}$ & $\begin{array}{l}\text { Fragaria } \mathrm{x} \\
\text { ananassa }\end{array}$ & LC633901 & LC633927 & LC633940 & LC633914 \\
\hline & SJB263 & $\begin{array}{l}\text { South } \\
\text { Korea }\end{array}$ & $\begin{array}{l}\text { Fragaria } \mathrm{x} \\
\text { ananassa }\end{array}$ & LC633902 & LC633928 & LC633941 & LC633915 \\
\hline & SJB271 & $\begin{array}{l}\text { South } \\
\text { Korea }\end{array}$ & $\begin{array}{l}\text { Fragaria } \mathrm{x} \\
\text { ananassa }\end{array}$ & LC633903 & LC633929 & LC633942 & LC633916 \\
\hline P. delsorboi & CBS 116708 & Netherlan & & LR026810 & LR026505 & LR026209 & LR025948 \\
\hline P. guizhouensis & CGMCC3.19658 & China & & MK880441 & МК930453 & MK930460 & MK880431 \\
\hline P. humicola & CBS 423.66 & & & $L R 026811$ & $L R 026506$ & $L R 026210$ & $L R 025949$ \\
\hline P. oligotrophica & CBS 440.90 & & & LR026814 & LR026509 & LR026211 & LR025952 \\
\hline P. pauciseptata & CBS 131745 & & & $L R 026816$ & $L R 026511$ & $L R 026212$ & $L R 025954$ \\
\hline \multirow[t]{4}{*}{ P. plurivora } & CBS 260.89 & & & LR026819 & LR026514 & LR026213 & LR025957 \\
\hline & CBS 292.66 & & & LR026822 & LR026517 & LR026214 & LR025960 \\
\hline & CBS 386.68 & & & $L R 026823$ & $L R 026518$ & $L R 026215$ & $L R 025961$ \\
\hline & CBS 642.63 & & & LR026826 & LR026521 & LR026216 & LR025964 \\
\hline P. ramiseptata & CBS 131743 & & & LR026831 & LR026529 & LR026224 & LR025969 \\
\hline P. nauculaspora & CGMCC3.19656 & China & & MK880439 & МК930451 & МК930458 & MK880424 \\
\hline $\begin{array}{l}\text { Brunneochlamydosporium } \\
\text { nepalense }\end{array}$ & CBS 277.89 & & & LR026683 & LR026385 & LR026111 & LR025812 \\
\hline
\end{tabular}

Multilocus phylogenetic analysis and species recognition

The obtained individual consensus sequences from Fusarium spp. were blasted against the Fusarium MLST database, and those obtained from Plectosphaerella spp. were blasted against GenBank to determine the closest matching species and species complex. Fungal species similar to the new isolates were used in phylogenetic analysis. Selected gene sequences of Fusarium spp. and Plectosphaerella spp. were downloaded from GenBank. All the fungal strain used in phylogenetic analysis are listed along with assigned GenBank accession numbers in Table 2. Individual gene sequences from the isolates belonging to the same genus were aligned using MEGA v.6.06 software (Tamura et al., 2013). The aligned sequences of Multiple genes/loci were concatenated in Mesquite v.2.75 (Maddison \& Maddison 2011). First, the single alignment of ITS, LSU, EF-1 $a$, and $r p b 2$ genes of Fusarium spp. isolates were used for phylogenetic analysis using the Fusarium MLST database. Second, a concatenated sequence of EF-1 $a$, and $r p b 2$ genes were used for phylogenetic inference based on two independent algorithms-Bayesian analyses (BI) and maximum likelihood (ML). Regarding Plectosphaerella spp. isolates, phylogenetic 
analysis based on $\mathrm{BI}$ and $\mathrm{ML}$ independent algorithms was conducted using a concatenated data set of ITS, LSU, EF-1 a, and rpb2. Mr Model Test v.2.3 (Nylander, 2004) was used for the best fit model. BI was run in Mr Bayes v.3.2.2 and ML in MEGA v.6.0 (Rorquist et al., 2012; Tamura et al., 2013). BI analysis included a Markov Chain Monte Carlo algorithm of four chains, with a stop rule option (split frequencies were below 0.01 ), and a tree was saved every 1000 generations. The $50 \%$ majority rule consensus trees and posterior probabilities (PP) were determined from the $75 \%$ held phylogenies after discarding $25 \%$ of the samples as the burn-in phase. The resulting trees were visualized using FigTree v.1.4.2 and MEGA v.6.0. For ML analyses, the bootstrap method (1000 replication), Tamura-Nei model, uniform rate, completed deletion and nearest-neighbor-interchange were used as default options.

\section{Morphological characterization}

Morphological characteristics of two representative isolates from each species were observed on PDA, oat-meal ager (OA), malt-extract agar (MA), corn-meal agar (CA), and V8 media after incubation at $25^{\circ} \mathrm{C}$ under $16 \mathrm{~h} \mathrm{light} / 8 \mathrm{~h}$ dark cycle. The fungal block (5mm) from the seven-day culture on PDA was transferred to the respective media. Each isolate was culture on three plates (90-mm petri dish) per media and two perpendicular measurements of colony diameter were determined every day for five-days. The size and shape of conidia, microconidia, macroconidia, chlamydospores, and conidiophores were examined and measured after mounting fungal structures slide glass in sterile water using light microscopy (Olympus BX43 microscope) at 400x magnification. The average and standard deviation were determined based on the measurement of 50 randomly selected conidia, microconidia, macroconidia, chlamydospores, and conidiophores each. Mycelial growth at various temperatures was evaluated. Mycelial block of approximate size $5 \times 5 \mathrm{~mm}$ were cut from the actively growing margin of the seven-day old culture on PDA, transferred on $90-\mathrm{mm}$ petri dish containing $25-\mathrm{ml} \mathrm{PDA}$, and then incubated at $15^{\circ} \mathrm{C}$, $18^{\circ} \mathrm{C}, 22^{\circ} \mathrm{C}, 25^{\circ} \mathrm{C}, 28^{\circ} \mathrm{C}, 30^{\circ} \mathrm{C}, 32^{\circ} \mathrm{C}$, and $35^{\circ} \mathrm{C}$ in complete darkness. The single-trial consisted of three PDA plates per isolate per temperature. The colony diameter was measured as described above.

\section{Pathogenicity assay}

For the pathogenicity test, strawberry seedlings (cultivars) were collected from the greenhouse and transplanted in a pot containing autoclaved pit soils. After transplanting, seedlings were placed in a growth chamber at $25^{\circ} \mathrm{C}$ and under $16 \mathrm{~h} / 8 \mathrm{~h} \mathrm{light} / \mathrm{dark}$ cycle and were watered regularly. The runner came out from the established plant. New strawberry plants were propagated by pegging down plantlets at the end runners into pots containing autoclaved pit soils. The plantlets were cut to free from the mother plant when they started to grow new leaves after approximately one month and were used for pathogenicity test. After seven days of -post-detaching from the mother plant, the plantlets were removed from pots, and the potting mixture was extracted from roots (shaking or with hand). Then, 10 replicate plants

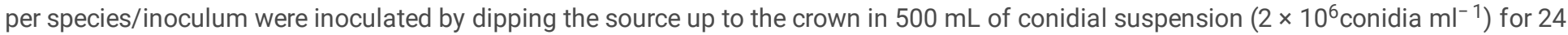
$\mathrm{h}$ in the dark. The conidial rest was prepared according to the aforementioned procedure. The same replicated control plants (10) per experiment were treated by dipping the root up to crown in 500-ml sterile deionized water for $24 \mathrm{~h}$ in the dark. After either inoculation or treatment, Strawberry plants were transplanted in the pot filled with the autoclaved potting mixture (pit soils: sand = 4:2), maintained in a growth chamber at $25^{\circ} \mathrm{C}$ and under $16 \mathrm{~h} / 8 \mathrm{~h}$ light/dark cycle, and irrigated daily with sterile water. Plants were monitored frequently to discover symptomatic plantlets.

Affected plantlets were further evaluated by observing the presence of root rot and discoloration inside the crown. Subsequently, the pathogen was reisolated and reidentified based on morphological characteristics and the sequence data of $r p b 2$ gene. Disease incidence (DI) was estimated as the proportion of symptomatic plantlets compared with the total number of inoculated plantlets.

\section{Statistical analyses}

The optimum temperature for the mycelial growth rate of the identified fungal species was estimated via nonlinear regression analysis using Gaussian four-parameter process in SigmaPlot v.14 (Systat Software, San Jose, CA). The mean and standard deviation (SD) of data were estimated using MS Excel. The growth rate of mycelium on various culture media was analyzed via ANOVA using SAS v.9.4, and Isd test was used to test for significant differences among or between different treatments at $P<0.05$.

\section{Results}

\section{Fungal isolation}

Thirty isolates were obtained from rotten tissue of the crown and root of $\sim 25$ affected strawberry plants collected from different greenhouses in Sangju, South Korea. Most of these isolates were Fusarium spp. (22 isolates) and the rest were Plectosphaerella spp. (eight isolates). Among the isolates belonging to Fusarium spp., the colony of majority isolates was pinkish-white (16 isolates), whereas the settlement of reaming hermits was creamy or off white (six isolates). 


\section{Multilocus phylogenetic analysis}

The multigene sequences from Fusarium spp. and Plectosphaerella spp. were subjected to phylogenetic analysis separately. The first phylogenetic tree illustrates the phylogenetic analysis among the Fusarium species, and the second one was among the Plectosphaerella spp. As the sequences of ITS,LSU, EF-1 $a$, and $r p b 2$ were not available for all reference isolates, separate phylogenetic analysis was conducted using individual sequence data. In this case, unique gene sequences of reference Fusarium spp. were obtained from Fusarium MLST and GeneBank database. The present isolates were clustered into two separate clades ( $F$. oxysporum species complex and $F$. solani species complex) consistently in the individual pyogenesis. The sequences of EF-1 $a$, and $r p b 2$ are believed to the more informative for Fusarium spp. identification. Thus, the concatenated sequence of $E F-1 a$, and $r p b 2$ were used to construct the multigene phylogenetic tree. Thirty-one representative Fusarium isolates, including the isolates from the current study and Brunneochlamydosporium nepalense as outgroup, were used to build the phylogenetic tree based on EF-1 $a$, and $r p b 2$ sequence data. The concatenated sequences data set comprised 1231 total characters, including gap. In BI, 50\% majority rules consensus tree with PP (Fig. 2) was estimated from the remaining 3920 trees after 1307 trees were discarded as the "burn-in" phase. Maximum likelihood analysis based on the Tamura-Nei model yielded the best ML tree with maximum log-likelihood of -4062.0432 . Codon positions included were $1 \mathrm{st}+2 \mathrm{nd}+3 \mathrm{rd}+$ noncoding, and there were a total of 733 places in the final dataset. Phylogenetic inference shows the position of all selected Fusarium isolate (nine isolates) (Fig. 2). Of these nine isolates, six were clustered in the $F$. oxysporum species complex and three in the $F$. solani species complex. The $F$. oxysporum species complex clade and three in $F$. solani species complex were highly supported ( $\mathrm{PP}=1 ; \mathrm{BS} \geq 90 \%$ ).

For the identification of Plectosphaerella spp., the multigene phylogenetic tree was constructed using the concatenated sequences of ITS, $L S U, E F-1 a$, and $r p b 2$. The analysis involved 21 representatives Plectosphaerella isolates, including the isolates from the current study and one Brunneochlamydosporium nepalense CBS 27789 (used as outgroup). The concatenated sequences dataset consists of 2400 characteristics, including gaps. The BI ended after 1 million generation, 50\% majority rules consensus tree with PP (Fig. 3) were estimated from 1085 trees left after the 272 trees were discarded as the burn-in phase. Maximum likelihood analysis yielded the best ML tree with maximum log-likelihood of -6629.1611 . The ML alignment matrix had 2307 positions in the final dataset, and the coding positions included were $1 s t+2 n d+3 r d+$ noncoding. The Tamura-Nei model was used to run the full likelihood analysis. The phylogenetic tree revealed the work of the isolates obtained in this study (Fig. 3). All the isolates clustered with reference isolates of $P$. cucumerina. The clade of $P$. cucumerina is highly supported by the posterior probability and bootstrap value ( $\mathrm{PP}=1 ; \mathrm{BS}=98 \%$ ).

\section{Morphological characterization}

Based on the molecular analysis, it was confirmed that the isolates obtained from the affected strawberry with crown and root rot from the five greenhouse belong to $F$. oxyporum species complex, $F$. solani species complex, and $P$. cucumerina. The morphological characteristics of representative isolate of identified fungal species described in detail.

\section{Morphological characterization of F. oxyporum species complex}

The colony and culture of F. oxyporum species complex isolate are shown in Fig. 3. The comparison of morphological characteristics of present and reference isolates of $F$. oxyporum species complex shown in Table 3. The colony of present isolate (SJB593) on PDA was white and purple, whereas the colony of reference isolate (CBS 144134) was vinaceous. The shape of macroconidia and chlamydospore of the present isolate match those of reference isolate described by Lombard et al. (2019). The present isolate produced cylindrical microconidia, whereas connection isolate produced ellipsoidal to falcate microconidia. The average size microconidia $(11.2 \times 3.9 \mu \mathrm{m})$ and chlamydospore $(12.0 \times 11.1 \mu \mathrm{m})$ of the present isolate were slightly bigger than that microconidium $(11.0 \times 3.0 \mu \mathrm{m})$ and chlamydospore $(\leq$ $10 \mu \mathrm{m}$ diameter) of reference isolate. The average size of macroconidia of the present isolate was $26.1 \times 4.7 \mu \mathrm{m}$, which is slightly smaller than that of macroconidia $(28.7 \times 5 \mu \mathrm{m})$ of reference isolate. 
Table 3

The comparison of morphological data including colony, macroconidia, and microconida for present and reference isolates of Fusarium spp.

\begin{tabular}{|c|c|c|c|c|c|}
\hline \multirow[t]{2}{*}{ Features } & & \multicolumn{2}{|c|}{ Fusarium oxysporum species complex } & \multicolumn{2}{|c|}{ Fusarium solani species complex } \\
\hline & & Present isolate (SJB593) & $\begin{array}{l}\text { Reference isolate } \\
\text { (CBS 144134) } \\
\text { (Lombard et al. } \\
\text { 2019) }\end{array}$ & Present isolate (SJB222) & $\begin{array}{l}\text { Reference isolate } \\
\text { (Yadou7-6) (Chang et al. } \\
\text { 2018) }\end{array}$ \\
\hline Colony on PDA & & $\begin{array}{l}\text { White, fluffy colonies and } \\
\text { purple on the back }\end{array}$ & $\begin{array}{l}\text { Vinaceous, floccose } \\
\text { with abundant aerial } \\
\text { mycelium }\end{array}$ & $\begin{array}{l}\text { White } \\
\text { colonies, reverse creamy } \\
\text { white }\end{array}$ & $\begin{array}{l}\text { Pale yellowish colonies, } \\
\text { reverse yellowish }\end{array}$ \\
\hline \multirow[t]{2}{*}{ Microconidia } & Shape & $\begin{array}{l}\text { Cylindrical and tapering } \\
\text { toward the end }\end{array}$ & Ellipsoidal to falcate & $\begin{array}{l}\text { Cylindrical, curve or } \\
\text { straight with blunted } \\
\text { ends }\end{array}$ & - \\
\hline & Size & $\begin{array}{l}8.3-16.3 \times 3.0-4.8 \mu \mathrm{m} \\
(\text { mean } \pm S D=11.2 \pm 1.9 \times \\
3.9 \pm 0.6 \mu \mathrm{m})\end{array}$ & $\begin{array}{l}6.0-15.0 \times 2.0-4.0 \\
\mu \mathrm{m}(\operatorname{mean}=11.0 \times \\
3.0)\end{array}$ & $\begin{array}{l}9.7-17.3 \times 3.4-8.3 \mu \mathrm{m} \\
(\operatorname{mean} \pm S D=12.9 \pm 2.3 \times \\
4.9 \pm 0.9 \mu \mathrm{m})\end{array}$ & - \\
\hline \multirow[t]{2}{*}{ Macroconidia } & Shape & Mostly falcate, septa 2-5 & Falcate, septa 1-5 & Falcate, septa 3-6 & $\begin{array}{l}\text { Cylindrical, falcate, } \\
\text { septa } 3\end{array}$ \\
\hline & Size & $\begin{array}{l}22.0-35.3 \times 3.9-5.6 \mu \mathrm{m} \\
(\mathrm{mean} \pm \mathrm{SD}=26.1 \pm 3.2 \times \\
4.7 \pm 0.5 \mu \mathrm{m})\end{array}$ & $\begin{array}{l}22.0-38.0 \times 4.0-5.0 \\
\mu \mathrm{m}(\operatorname{mean}=28.7 \times 5 \\
\mu \mathrm{m})\end{array}$ & $\begin{array}{l}26.6-45.5 \times 4.5-8.8 \mu \mathrm{m} \\
(\operatorname{mean} \pm S D=33.0 \pm 4.8 \times \\
6.5 \pm 1.1 \mu \mathrm{m})\end{array}$ & $\begin{array}{l}25-30.2 \times 4.1-4.6 \mu \mathrm{m} \\
(\mathrm{mean} \pm S D=27.2 \pm 1.9 \\
\times 4.3 \pm 0.2 \mu \mathrm{m})\end{array}$ \\
\hline \multirow[t]{2}{*}{ Chlamydospore } & Shape & Globose & $\begin{array}{l}\text { Globose to } \\
\text { subglobose }\end{array}$ & Globose,single or in pair & - \\
\hline & Size & $\begin{array}{l}8.6-15.7 \times 7.6-14.3 \mu \mathrm{m} \\
(\operatorname{mean} \pm \mathrm{SD}=12.0 \pm 2.1 \times \\
11.1 \pm 1.9 \mu \mathrm{m})\end{array}$ & 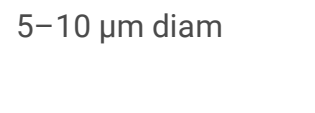 & $\begin{array}{l}6.8-10.9 \times 6.6-11.6 \mu \mathrm{m} \\
(\operatorname{mean} \pm S D=9.2 \pm 1.2 \times \\
8.7 \pm 1.2 \mu \mathrm{m})\end{array}$ & - \\
\hline
\end{tabular}

\section{Morphological characterization of F. solani species complex isolate}

Colony and microscopic characteristics of present isolate belonging to F. solani species complexes are shown in Fig. 5 . The morphological characteristics, including colony color, shape, and size of microconidia, macroconidia, and chlamydospore of presents isolate, were comparable with those of reference isolate described by Chang et al. (2018) (Table 3). The colony color of the present isolate (SJB222) was white from up and creamy white from the reverse side, whereas Chang et al. (2018) described the colony color of the isolate (Yadou7-6) as a pale yellowish and yellowish on the back. The shape of macroconidia produced in present isolates is consistent with the shape of macroconidia of reference isolate. The present isolates had bigger macroconidia $(33.0 \times 6.5 \mu \mathrm{m})$ than that of the reference isolate. Miroconida of present isolates were cylindrical, curve, or straight and were $9.7-17.3 \times 3.4-8.3 \mu$ in diameter. The chlamydospore produced by the present isolate were globose, pair form, and were $6.8-10.9 \times 6.6-11.6 \mu \mathrm{m}$ in diameter.

\section{Morphological characterization of $\mathrm{P}$. cucumerina isolate}

The colony and culture of $P$. cucumerina are shown in Fig. 6. The comparison of morphological characteristics of present and reference isolate of $P$. cucumerina are shown in Table 4. The morphological characteristics of the present isolate are comparable with that of the reference isolate of $P$. cucumerina (CBS131739) described by Carlucci et al. (2012). The colony of the present isolate was creamy white and pale yellowish from the reverse side. Conidiophores were simple (rarely branched) and were 10.6-44.9 $\times 2.2-5.4 \mu \mathrm{m}$ in diameter. Conidia were ellipsoidal, tapered or rounded ends, guttate, $0-1$ septate, and 8.5-13.1 × 3.2-6.4 $\mu$ m in diameter. On average, the conidial size of present isolates was bigger than that of reference isolates. Carlucci et al. (2012) described the conidial size of $P$. cucumerina (CBS131739) as 7-10.5 × 2.5-3.5 $\mu \mathrm{m}$ (mean $\pm \mathrm{SD}=8.8 \pm 1.3 \times 2.8 \pm 0.4 \mu \mathrm{m})$ in diameter. 
Table 4

The comparison of morphological data, including colony, mycelium, conidiophore, and conidia for present and reference isolates of $P$. cucumerina.

\begin{tabular}{|c|c|c|c|}
\hline \multirow{2}{*}{\multicolumn{2}{|c|}{ Features }} & \multicolumn{2}{|l|}{ Plectosphaerella cucumerina } \\
\hline & & Present isolate (SJB271) & $\begin{array}{l}\text { Reference isolate(CBS 131739) (Carlucci et } \\
\text { al.2012) }\end{array}$ \\
\hline \multicolumn{2}{|l|}{ Colony on PDA } & Creamy white colonies, reverse pale yellowish & Various shades of buff to salmon pink \\
\hline \multicolumn{4}{|l|}{ Mycelium } \\
\hline & & $\begin{array}{l}\text { Hyaline, septate, branched, forming hyphal coils, } 2.5-5.2 \\
\mu \mathrm{m}(\text { mean } \pm S D=4.2 \pm 0.9 \mu \mathrm{m}) \text { wide. }\end{array}$ & Hyaline, septate, branched, forming hyphal coils \\
\hline \multirow[t]{2}{*}{ Conidiophore } & Shape & Simple or rarely branched & $\begin{array}{l}\text { Solitary, unbranched or rarely irregularly } \\
\text { branched }\end{array}$ \\
\hline & Size & $\begin{array}{l}10.6-44.9 \times 2.2-5.4 \mu \mathrm{m}(\text { mean } \pm S D=26.9 \pm 11.3 \times 3.3 \pm \\
0.8 \mu \mathrm{m})\end{array}$ & - \\
\hline \multirow[t]{2}{*}{ Conidia } & Shape & $\begin{array}{l}\text { Ellipsoidal, tapered or rounded ends, guttulate, } 0-1 \\
\text { septate }\end{array}$ & $\begin{array}{l}\text { Ellipsoidal, tapering gradually to rounded apex } \\
\text { and base, guttulate, } 0-1 \text { septate }\end{array}$ \\
\hline & Size & $\begin{array}{l}8.5-13.1 \times 3.2-6.4 \mu \mathrm{m}(\text { mean } \pm S D=10.6 \pm 1.3 \times 4.3 \pm \\
0.7 \mu \mathrm{m})\end{array}$ & $\begin{array}{l}7-10.5 \times 2.5-3.5 \mu \mathrm{m}(\text { mean } \pm S D=8.8 \pm 1.3 \times \\
2.8 \pm 0.4 \mu \mathrm{m})\end{array}$ \\
\hline
\end{tabular}

\section{Effect of culture media and temperature on mycelial growth}

The media have a significant influence on the mycelial growth rate (Fig. 7). The isolates of $F$. solani showed the highest growth rate on PDA, MEA, V8 and the least growth rate on CMA. In contrast, the isolates of $F$. oxyporum showed the best growth rate on $\mathrm{V} 8$ followed by CMA, OMA and the least growth rate on MEA. The growth rate of the isolate of $P$. cucumerina was significantly higher on $\mathrm{V} 8$ and $\mathrm{CMA}$ than on PDA, MEA, and OMA (Fig. 7A). The mycelium growth rate on the same culture media also depends on fungal species (Fig. 7B). For example, F. oxyporum grew significantly well on OMA followed by F. solani and $P$. cucumerina, whereas $F$. solani grew significantly better on MEA followed by F. oxyporum and P. cucumerina. Plectrosporium cucumerina showed poor growth rate on all tested media compared with that of $F$. solani and F. Oxyporum (Fig. 7B). The selected isolates representing each of the three fungal species were grown on PDA at $15^{\circ} \mathrm{C}-35^{\circ} \mathrm{C}$. The maximum growth rate of $F$. solani species complex (isolate SJB222) was estimated at $25.2^{\circ} \mathrm{C}$. In contrast, the top growth rates of F. oxysporum species complex (isolate SJB593) and P. cucumerina (isolate SJB271) were $22.0^{\circ} \mathrm{C}$ and $22.7^{\circ} \mathrm{C}$, respectively (Fig. 8 ). Plectrosporium cucamarina exhibited the slowest growth rate at all tested temperature regimes. F. solani species complex (isolate SJB222) showed the highest growth rate at higher temperature $\left(22.5^{\circ} \mathrm{C}-35^{\circ} \mathrm{C}\right)$, whereas $F$. oxysporum species complex showed at lower temperature $\left(15^{\circ} \mathrm{C}-22.5^{\circ} \mathrm{C}\right)$.

\section{Pathogenicity test}

To confirm Koch's postulates, the pathogenicity of an identified representative isolate of F. oxyporum species complex (SJB593), F. solani species complex (SJB222), and P. cucumerina (SJB271) were tested by following the root dip assay method. The pant showed typical crown and root rot symptoms after 15 (Fusarium spp.) and 18 ( $P$. cucumerina) days of inoculation (Fig. 9). The symptoms include wilting, root rot, and discoloration inside the crown, which was similar to those observed naturally infected plantlet in greenhouse. But tested isolate showed a different level of aggressiveness intern of DIs. The hermit of $P$. cucumerina showed the highest virulence with $80 \%$ DI followed by F. solani species complex with $70 \%$ and F. oxyporum species complex with $60 \% \mathrm{DI}$. The control plant remains healthy and asymptomatic (Fig. 9).

\section{Discussion}

The crown and root rot disease is a significant threat to strawberry production worldwide (Fang et al., 2011). According to the grower at Sangju, South Korea, the level of the crown and root rot in strawberry greenhouse increase in the late production season. Low pH levels (4.5-6) influence the outbreak of this disease (Fang et al., 2011). Three fungal species were recovered from the deceased strawberry crown and were discerned as F. oxyporum species complex, F. solani species complex, and $P$. cucumerina based on distinct molecular and morphological characteristics. The pathogenicity assay revealed that the isolates of these fungal species reproduced identical disease symptoms. Therefore, this study concluded $F$. oxyporum species complex, $F$. solani species complex, and $P$. cucumerina are responsible for 
the crown and root rot of strawberry in Sangju, South Korea. F. oxyporum species complex were the most reported fungal species that cause crown and root rot of strawberry, but this is the first report showing $F$. solani species complex and $P$. cucumerina as the causative agent of this disease. Proper diagnosis of this new pathogen is crucial because early identification and disease monitoring are the most important critical steps for implementing any disease management program (Riley et al., 2002).

With the progress in molecular analysis and bioinformatics, the crystal explicit knowledge regarding fungi and their association with the host has increased over the last decade (Chung et al., 2020). The multigene phylogenetic approach uses sophisticated and reliable tools for the classification of cryptic fungal taxa and fungi, including plant pathogen. The filamentous fungal genus Fusarium is one of the most destructive plant pathogen comprised of 300 phylogenetically distinct species distributed among 23 species complex (O'Donnell et al., 2015; Dongzhen et al., 2020). Initially, fungal species within the Fusarium genus were identified based on iconic fusiform multiseptate macroconidia. The morphological and morphological phylogenetic studies revealed that they convergently evolved into different lineages of ascomycetes (O'Donnell et al., 2015). So, the use of molecular markers (DNA sequences) is more reliable for identifying closely related species. In this study, we identified $F$. oxyporum and $F$. solani species complex based on phylogenetic inference using concatenated sequences of EF-1 $a$, and $r p b 2$. The sequences of EF-1 $a$ and $r p b 2$ highly recommend for phylogenetic analysis and BLASTn against curated reference sequences in the FUSARIUM-ID and Fusarium MLST database for identification to assess species-level identification within the genus Fusarium (O’Donnell et al., 2015; Šišić et al., 2018). In this study, these loci showed high potential to distinguish the different Fusarium species complex, including the F. oxyporum and F. solani species complex.

Plectosporium was first described in 1995 as the new genus for the species previously known as Fusarium tabacinum (Cephalosporium tabacinum), the anamorph of Plectosphaerella cucumerina (Palm et al., 1995). Some studies recommend using LSU, ITS, EF1a, and RPB2 sequences data to resolve the taxonomy of the Plectosphaerella species (Giraldo \& Crous 2019; Zhang et al., 2019). This study also found that the concatenated sequences of these loci are very informative for identifying $P$. cucumerina.

The morphological characteristics of identified fungal species in this study were comparable with that of the respective reference species and species complex (Tables 3 and 4). This study found that there are some differences in morphological characteristics; for example, macroconidia of the present isolate of F. oxyporum species complex (SJB 593) were smaller than that of reference isolate (CBS 144134), whereas macroconidia of the present isolate of $F$. solani species complex (SJB222) were larger than that of reference isolate Yadou7-6 (Table 3). The conidia of $P$. Cucumerina also isolates are larger than that of reference isolate CBS 131739. The slight morphological differences within the same species are explained by the difference in host, geographical location, and cultural condition. Many studies reported that morphological characteristics fungal species are influenced by the host, geographical location, culture media, and cultural condition (Stewart et al., 2006; Weir et al., 2012; Hassan et al. 2018). This study also found that F. oxyporum species grew well on PDA and V8 and F. solani and P. cucumerina on V8 and CMA. So, V8 could be the best choice to culture these species.

Among the fungal species, Fusarium species exhibited greater mycelial growth in warm temperature (Fig. 8). The adaptability of Fusarium species in warm temperature explain its current geographical distribution. Warm and rainfall are the favorable condition for Fusarium species to infect crops (Doohan et al., 2003). In contrast, the favorable condition for $P$. cucumerina were high humidity and low temperature $\left(20^{\circ} \mathrm{C}-26^{\circ} \mathrm{C}\right)$ (Gilardi et al., 2012).

In general, both Fusarium species (F. oxyporum and $F$. solani) soil in-habiting species capable of causing disease, including wilt, root rot and crown rot of all economically important crops. In South Korea, F. oxyporum has been reported as the causative agent for wilt of many plant species, including prickly lettuce, larch, and chrysanthemum (Kwon et al., 2013; Hassan et al., 2019; Kim \& Choi 2020). In contrast to F. oxyporum, F. solani is not a frequently reported fungal species in South Korea. It has been reported as the causative agent wilt of cucumber coastal hog fennel and sweet potato (Han et al., 2012; Yang et al., 2018; Kwon et al., 2020). To the best of our knowledge, $F$. solani has not been reported as the causative agent of crown and root rot of strawberry in South Korea. Like Fusarium spp., $P$. cucumerina also soil inhabiting plant pathogen and has been reported on many crops, including alfalfa, cabbage, potato, tomato, and sunflower (Abad et al., 2000; Li et al., 2017). Though having a wide host range, it was reported only on the wild arrowhead in South Korea (Li et al., 2017). To the best of our knowledge, this is the first report of root and crown rot of strawberry caused by $P$. cucumerina in South Korea.

Evolving of the new pathogen under existing cultural practices and control methods indicates that it is necessary to adopt new cultural practices and control strategies. Strawberry grower in Sangju use river water for irrigation. Inoculum of this disease may come through contaminated irrigated water. Plant debris of affected plant also a crucial source of inoculum. Plant debris was observed during the survey. This plant debris may be mixed with soil in pot mixture and infect the newly propagated plantlet. Proper disposal of affected plant debris is necessary. For developing chemical strategies to control this disease, a representative isolate of identified fungal taxa in this study needs to be tested for estimation of efficacy of traditional fungicides (benomyl, captan, mefenoxamand thiophanate methyl).

Page $11 / 20$ 
In conclusion, the finding of this study indicates essential information to develop sustainable control measures for crown and root rot of strawberry in South Korea.

\section{Declarations}

\section{Acknowledgment}

We would like to thank all the members of the plant pathology lab, Kyungpook National University, for their valuable support during this study.

Disclosure of potential conflicts of interest:The authors declare no conflicts of interest

Research involving Human Participants and/or Animals:There was no involvement of Human Participants and/or Animals in this research

Informed consent: Not applicable

Funding: Self funded (Funded by Taehyun Chang)

Availability of data and material:Avialble on request

Code availability: Not applicable

\section{References}

1. Abad, P., Pérez, A., Marqués, M. C., Vicente, M. J., Bruton, B. D.\& García-Jiménez, J.(2000). Assessment of vegetative compatibility of Acremonium cucurbitacearumand Plectosphaerella cucumerina isolates from diseased melon plants. Bulletin OEPP, 30(2), 199204.

2. Carlucci, A., Raimondo, M. L., Santos, J. \& Phillips, A. J. (2012). Plectosphaerella species associated with root and collar rots of horticultural crops in southern Italy. Persoonia, 28, 34-48.

3. Chang, X., Dai, H., Wang, D. Zhou, H., He, W., Fu, Y., Ibrahim, F., Zhou, Y., Gong, G. Shang, J., Yang, J., Wu, X., Yong, T., Song, C. \& Yang,W. (2018). Identification of Fusariumspecies associated with soybean root rot in Sichuan Province, China. EurrpeanJournal ofPlant Pathology, 151, 563-577.

4. Chung, P. C., Wu, H. Y., Wang, Y. W., Ariyawansa, H. A., Hu, H. P., Hung, T. H., Tzean, S. S. \& Chung, C. L. (2020). Diversity and pathogenicity of Colletotrichum species causing strawberry anthracnose in Taiwan and description of a new species, Colletotrichum miaoliense nov. ScientificReport, 10, 14664.

5. Dongzhen, F., Xilin, L., Xiaorong, C., Wenwu, Y., Yunlu, H., Yi, C., Jia, C., Zhimin, L., Litao, G., Tuhong, W., Xu, J. \&Chunsheng, G. (2020). FusariumSpecies and Fusarium oxysporum Species Complex Genotypes Associated With Yam Wilt in South-Central China. Frontiers in microbiology, 11, 1964.

6. Doohan, F. M., Brennan, J. \& Cooke, B. M. (2003). Influence of climatic factors on Fusarium species pathognic to cereals. Eurrpean Journal ofPlant Pathology, 109, 755-768.

7. Fang, X. L., Phillips, D., Li, H., Sivasithamparam, K. \& Barbetti, M.J. (2011). Severity of crown and root diseases of strawberry and associated fungal and oomycete patho- gens in Western Australia. Australasian Plant Pathology40, $109-119$.

8. Fang, X., Phillips, D., Verheyen, G., Li, H., Sivasithamparam, K. \& Barbetti, M. (2012). Yields and resistance of strawberry cultivars to crown and root diseases in the field, and cultivar responses to pathogens under controlled environment conditions. Phytopathologia. Mediterranae,51, 69-84.

9. Geiser, D. M., Jiménez-Gasco, M., Kang, S., Makalowska, I., Veeraraghavan, N., Ward, T. J., Zhang, N. Kuldau, G.A. \&O’Donnell, K., (2004). FUSARIUM-ID v.1.0: A DNA sequence database for identifying Fusarium. EurrpeanJournal ofPlant Pathology,110, $473-479$.

10. Gilardi, G., Bergeretti, F., Gullino, M. L.\& Garibaldi, A. (2019). First Report of Neopestalotiopsis clavispora Causing Root and Crown Rot on Strawberry in Italy. Plant disease, 103, 2959.

11. Gilardi, G., Ortu, G., Gullino, M. L.\& Garibaldi, A. 2012. Plectosphaerella cucumerina: a new pathogen on wild rocket in Italy. Protezione dele Colture, 5, 31-33. (Summery in English).

12. Han, K.S., Lee, S.C., Han, Y.K., Kim, D.H. \& Kim, S. (2012). Crown and Foot Rot of Grafted Cucumber Caused by Fusarium solani sp. cucurbitae. ResearchPlantDisease, 18, 57-61. 
13. Hassan, O. Lim, T.-H. \& Chang, T. (2019). Damping-Off of Larch (Larix kaempferi) Caused by Fusarium oxysporumin Korea. Plant Disease, 103, 1037-1037.

14. Hassan, O., Jeon, J. Y., Chang, T., Shin, J. S. \& Oh, N. K. (2018). Molecular and morphological characterization of Colletotrichumspecies in the Colletotrichum gloeosporioides complex associated with persimmon anthracnose in South Korea. Plant Disease, 102, 10151024.

15. Hellin, P., Scauflaire, J., Van Hese, V., Munaut, F. \&Legrève, A. (2017). Sensitivity of Fusarium culmorum to triazoles: impact of trichothecene chemotypes, oxidative stress response and genetic diversity. Pest management science, 73(6), $1244-1252$.

16. Kim, B. R. and Choi, Y. J. 2020. Fusarium fujikuroiCausing Fusarium Wilt of Lactuca serriola in Korea. Plant Disease, 105, $502-502$.

17. (2009). The Korean Society of Plant Pathology. List of plant diseases in Korea. 5th ed. Seoul: Korean Society of Plant Pathology.

18. Kwon, J. H., Choi, O. \&Kim, J. (2013). Fusarium oxysporum Causing Wilt and Stem Rot in Chrysanthemum $\times$ morifolium in Korea. Plant disease, 97 ,

19. Kwon, S. K., Jeon, C.W. \& Kwak, Y. S. (2020). First Report of Wilt Disease on Peucedanum japonicum and Selection of Fungicides. The Korean Journal of Pesticide Science,24, 7-13. (Abstract in English).

20. Li, P. L., Chai, A. L., Shi, Y. X., Xie, X. W. \& Li, B. J. (2017). First Report of Root Rot Caused by Plectosphaerella cucumerinaon Cabbage in China. Mycobiology, 45, 110-113.

21. Lombard, L., Sandoval-Denis, M., Lamprecht, S. C. \& Crous, P. W. (2019). Epitypification of Fusarium oxysporum clearing the taxonomic chaos. Persoonia,43,1-47.

22. Maddison, W. P. and Maddison, D. R. (2011). Mesquite: a modular system for evolutionary analysis. Version 2.75. http://mesquiteproject.org.

23. Maryani, N., Lombard, L., Poerba, Y.S., Subandiyah, S., Crous, P.W. \& Kema, G.H.J. (2019).Phylogeny and genetic diversity of the banana Fusarium wilt pathogen Fusarium oxysporum sp. cubense in the Indonesian centre of origin. Studies in Mycology,92, 155194.

24. Nam, M. H., Kim, H. S., Park, M. S., Min, J. Y. and Kim, H. T. (2020). Genetic Diversity, Pathogenicity, and Fungicide Response of Fusarium oxysporum sp. fragariae Isolated from Strawberry Plants in Korea. Research inPlantDisease,26, 79-87.

25. Nylander, J. A. A. (2004). MrModelTest v2. Program Distributed by the Author. Uppsala, Sweden: Evolutionary Biology Centre, Uppsala University.

26. O’Donnell, K., Ward, T.J., Robert, V.A.R.G., Crous, P.W., Geiser, D. M. and Kang, S.(2015).DNA sequence-based identification of Fusarium: Current status and future directions. Phytoparasitica, 43, 583-595.

27. O'Donnell, K., Sutton, D. A., Rinaldi, M. G., Sarver, B. A., Balajee, S. A., Schroers, H. J., Summerbell, R. C., Robert, V. A., Crous, P. W., Zhang, N., Aoki, T., Jung, K., Park, J., Lee, Y. H., Kang, S., Park, B. \& Geiser, D. M. (2010). Internet-accessible DNA sequence database for identifying fusaria from human and animal infections. J Journal of clinical microbiology,48, 3708-3718.

28. Palm, M. E., Gams, W. \& Nirenberg, H. I. (1995). Plectosporium, a new genus for Fusarium tabacinum, the anamorph of Plectosphaerella cucumerina. Mycologia,87, 397-406.

29. Park, K., Han, I., Lee, S.-M., Choi, S.-L., Kim, M. C. \& Lee, H. (2019). Crown and Root Rot of Strawberry Caused by Neopestalotiopsis clavispora in Korea. TheKoreanJournal ofMycology,47, 427-435. (Abstract in English).

30. Ramdial, H., De Abreu, K. \& Rampersad, S. N. (2017). Fungicide Sensitivity among Isolates of Colletotrichum truncatumand Fusarium incarnatum-equiseti Species Complex Infecting Bell Pepper in Trinidad. ThePlant PathologyJournal, 33, 118-124.

31. Rehner, S. A.\&Samuels, G. J. (1994). Taxonomy and phylogeny of Gliocladium analysed from nuclear large subunit ribosomal DNA sequences. MycologicalResearch,98, 625-634.

32. Riley, M.B., Williamson,M.R. \& Maloy, O. (2002). Plant disease diagnosis. The Plant Health Instructor. DOI: 10.1094/PHI-I-2002-1021-01

33. Ronquist, F., Teslenko, M., van der Mark, P., Ayres, D.L., Darling, A., Höhna, S., Larget, B., Liu, L., Suchard, M. A.\&Huelsenbeck, J.P. (2012). MrBayes 3.2: efficient Bayesian phylogenetic inference and model choice across a large model space. Systematic biology, 61(3), 539-542.

34. Šišić, A., Al-Hatmi, A., Baćanović-Šišić, J., Ahmed, S. A., Dennenmoser, D., de Hoog, G. S. and Finckh, M. R. (2018). Two new species of the Fusarium solani species complex isolated from compost and hibiscus (Hibiscus sp.). Antonie van Leeuwenhoek, 111(10), 17851805.

35. Stewart, J. E., Kim, M.-S., James, R. L., Dumroese, R. K. \& Klopfenstein, N. B. (2006). Molecular characterization of Fusarium oxysporum and Fusarium commune isolates from a conifer nursery. Phytopathology,96,1124-1133. 
36. Surovy, M.Z., Kabir, M.K., Gupta, D. R., Hassan, O., Mahmud, N.U., Sabir, A.A., Rahman, M., Chang, T., Panaccione, D. G. \& Islam, M. T. (2019). First report of Fusarium wilt caused by Fusarium oxysporum on strawberry in Bangladesh. Plant Disease,103, 367-368.

37. Tamura, K., Stecher, G., Peterson, D., Filipski, A. \& Kumar, S. (2013). MEGA6: Molecular Evolutionary Genetics Analysis Version 6.0. Molecular biology and evolution, 30(12), 2725-2729.

38. Taylor, J. W., Jacobson, D. J., Kroken, S., Kasuga, T., Geiser, D. M., Hibbett, D. S. \& Fisher, M.C. (2000). Phylogenetic species recognition and species concepts in fungi. Fungal genetics and biology : FG \& B, 31(1), 21-32.

39. Vilgalys, R. and Hester, M. (1990). Rapid genetic identification and mapping of enzymatically amplified ribosomal DNA from several Cryptococcus Journal of bacteriology, 172(8), 4238-4246.

40. Wei, H., Liu, C. \& Ryong Jeong, B. (2020). An Optimal Combination of the Propagation Medium and Fogging Duration Enhances the Survival, Rooting and Early Growth of Strawberry Daughter Plants. Agronomy,10,

41. Weir, B. S., Johnston, P. R. \&Damm, U. (2012). The Colletotrichum gloeosporioides species complex. Studies in Mycology,73, $115-80$.

42. White, T.J. Bruns, T. \&Taylor, J. (1990). Amplification and direct sequencing of fungal ribosomal RNA genes for phylogenetics. In: Innis MA, Gelfand DH, Sninsky JJ et al (eds) PCR protocols: a guide to methods and applications. Academic Press, San Diego, pp $315-322$.

43. Yang, J. W., Nam, S. S., Lee, H. U., Choi, K. H., Hwang, S. G. \& Paul, N. C. (2018). Fusarium root rot caused by Fusarium solanion sweet potato (Ipomoea batatas) in South Korea. Canadian Journal ofPlantPatholology, 40, 90-95.

44. Zhan, Y.J., Peng, W.J., Xu, Z.Q., Xu, H. \& Feng, X.H. First Report of Phytopythium helicoidesCausing Root and Crown Rot on Strawberry in China. Plant disease, $104,2528$.

45. Zhang, Z. Y., Chen, W. H., Zou, X., Han, Y. F., Huang, J. Z., Liang, Z. Q.\& Deshmukh, S. K. 2019. Phylogeny and taxonomy of two new Plectosphaerella (Plectosphaerellaceae, Glomerellales) species from China. MycoKeys, 57, 47-60.

\section{Figures}
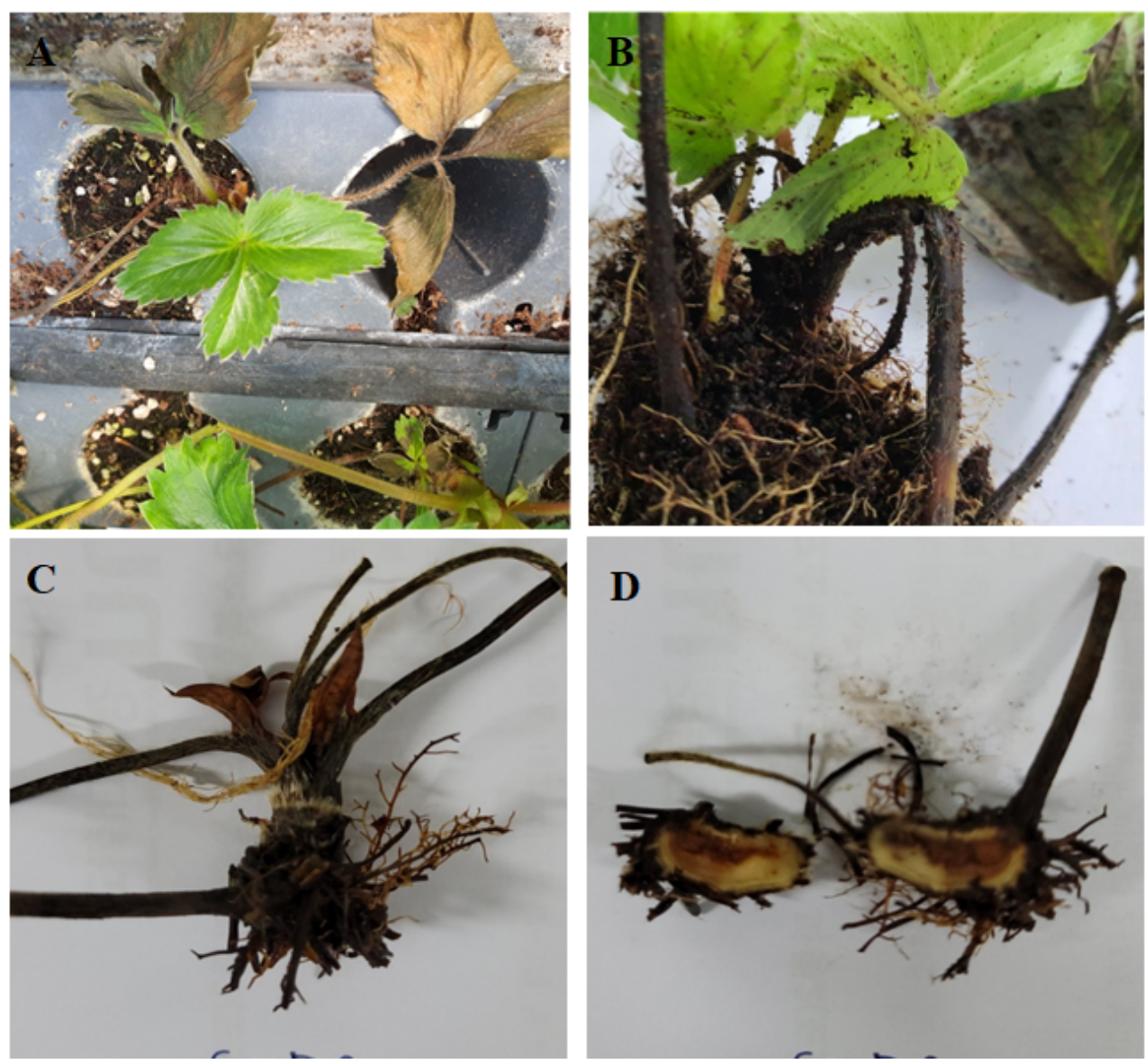

Figure 1

Crown and root rot of strawberry;A-B: affected strawberry plants in green house;C: root and crown discoloration in wilted and collapse strawberry plant in green house; $\mathrm{D}$ : crown discoloration. 


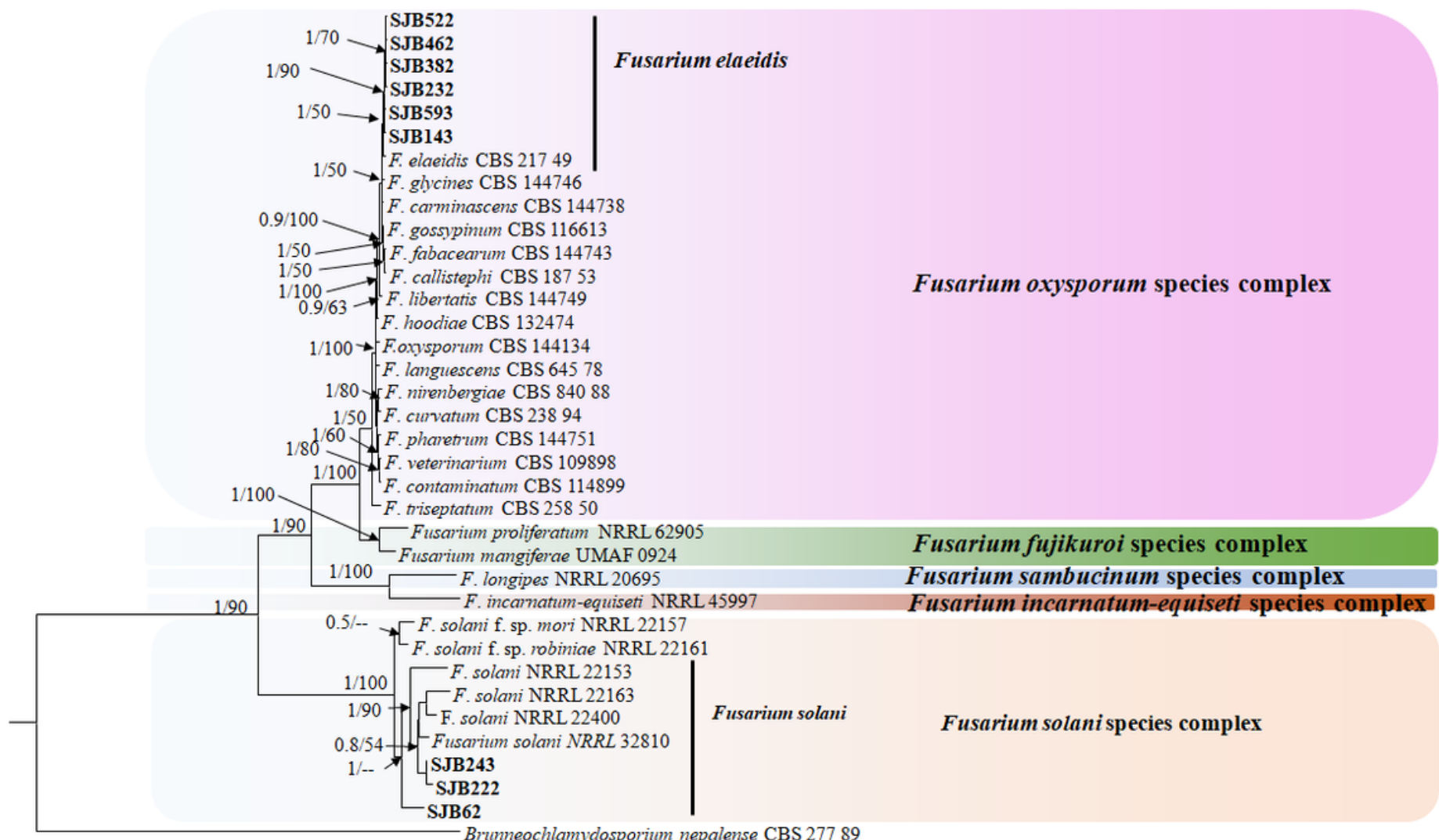

0.1

Figure 2

A Bayesian inference phylogenetic tree based on combined EF1-a and rpb2 sequence alignment of Fusarium spp. The present isolates are indicated in bold color. Bayesian posterior probability ( $P P \geq 0.50$ ), maximum likelihood bootstrap support values (ML $\geq 50$ )are shown at the nodes (PP/ML). The scale bar shows the expected number of substitutions per site. 


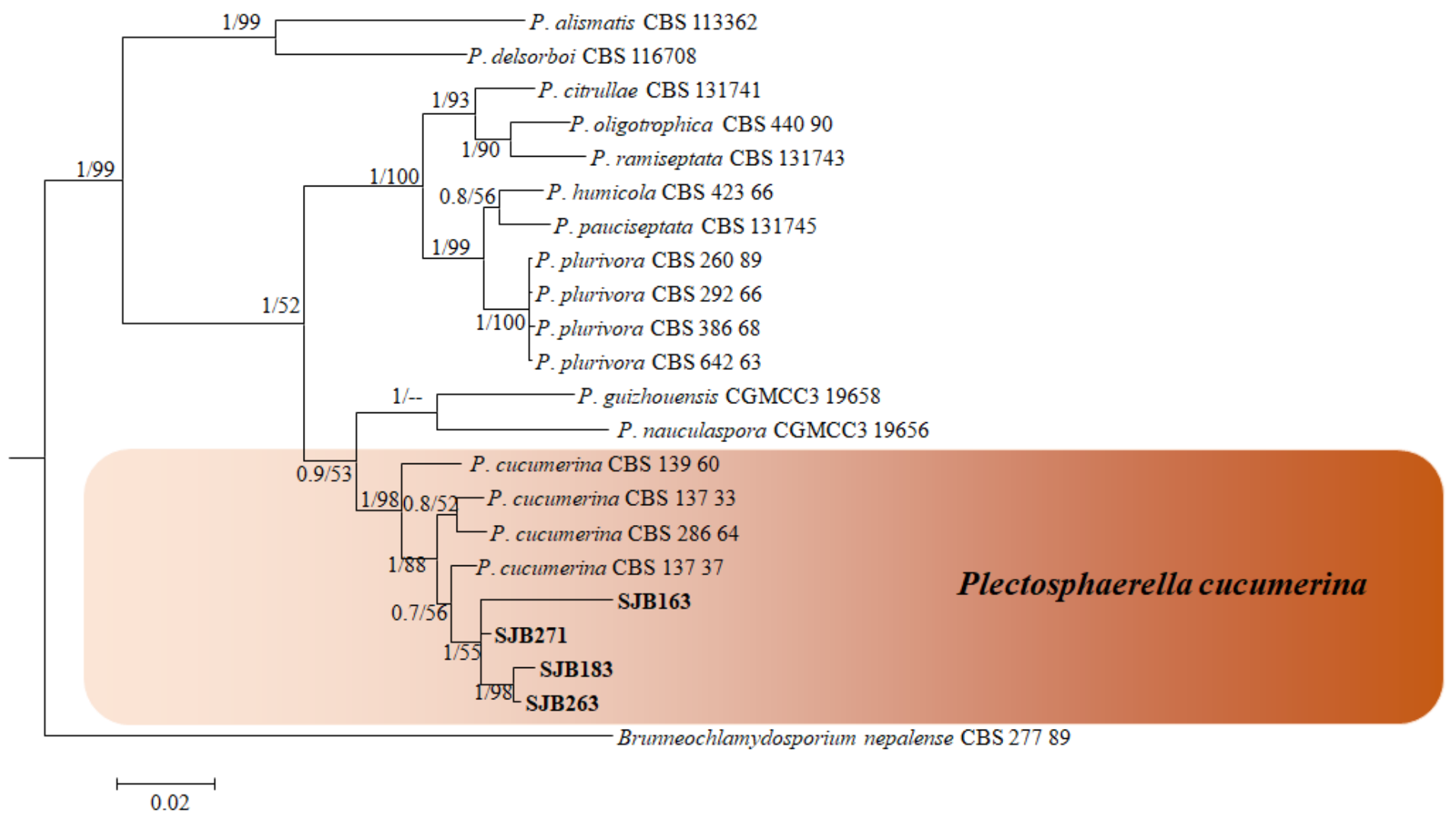

\section{Figure 3}

A Bayesian inference phylogenetic tree based on combined ITS, LSU, EF1-a, and rpb2 sequence alignment of Plectosphaerella spp. The present isolates are indicated in bold color. Bayesian posterior probability ( $P P \geq 0.50$ ), maximum likelihood bootstrap suport values ( $M L \geq$ 50)are shown at the nodes (PP/ML). The scale bar shows the expected number of substitutions per site.
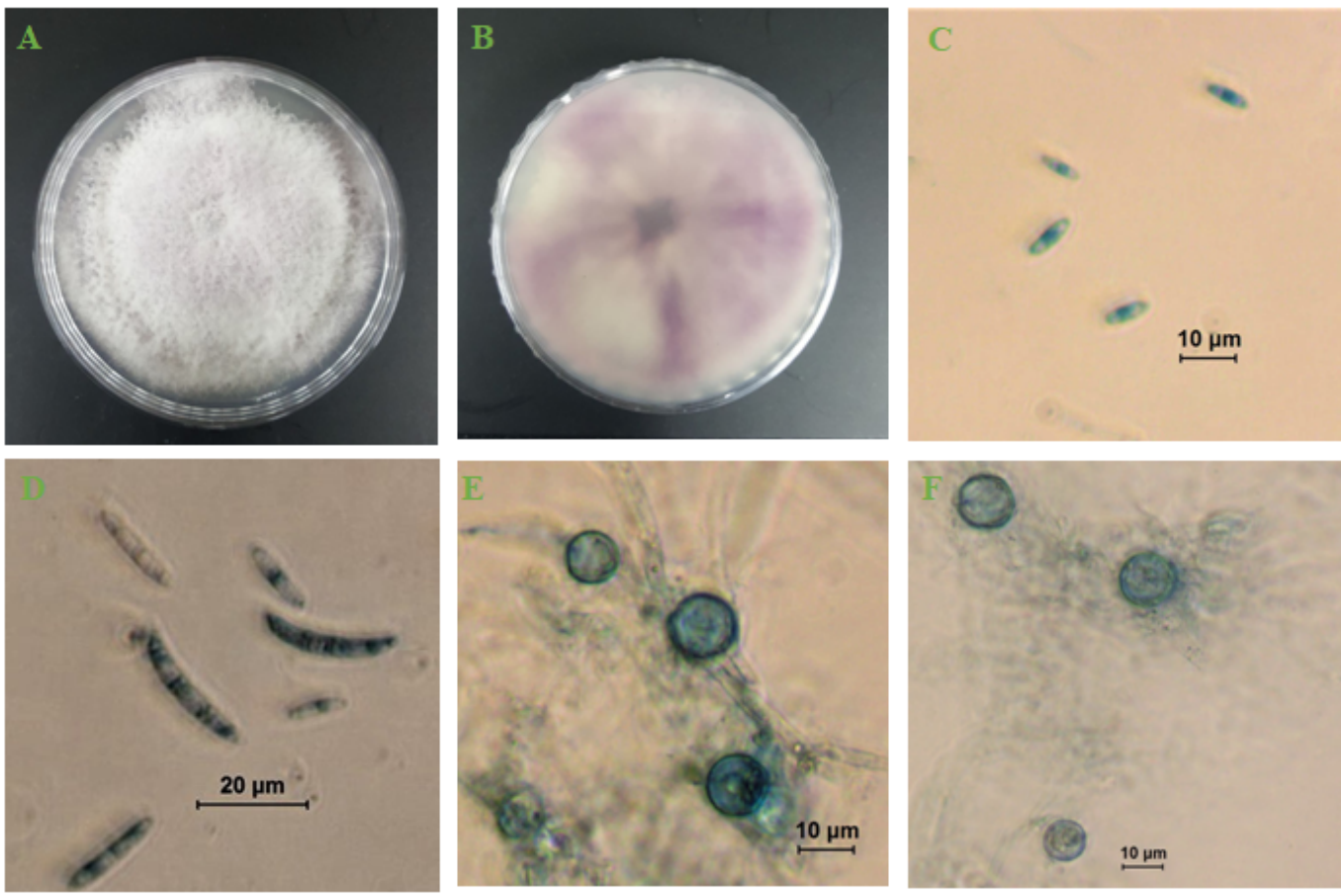

\section{Figure 4}

Morphological characteristics of Fusarium oxysporum species complex (isolate SJB593);A-B: Colony on PDA. C: Microconidia;D: Macroconidia;E-F: Clamidospore. 

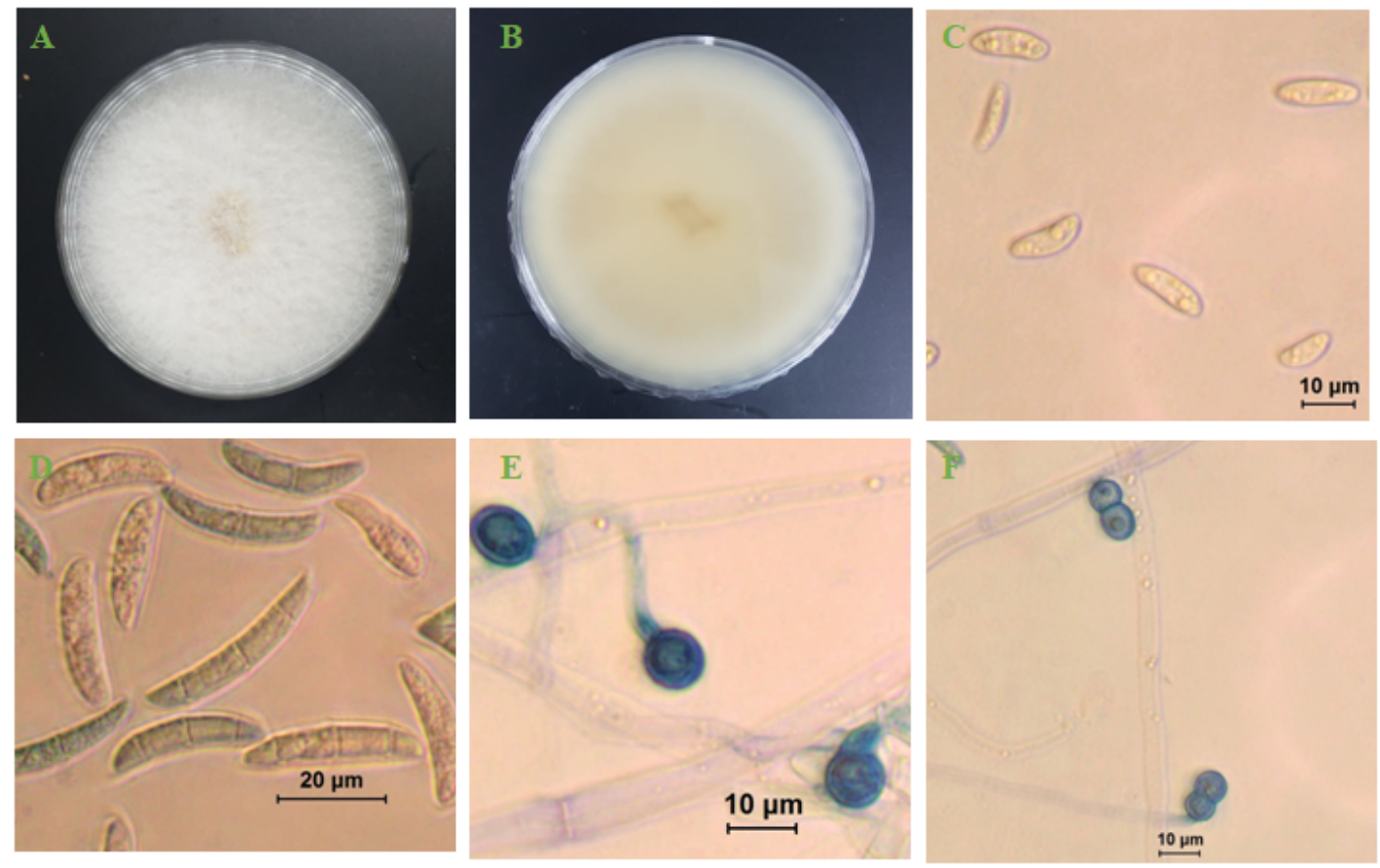

\section{Figure 5}

Morphological characteristics of Fusarium solani species complex (isolate SJB222);A-B: Colony on PDA;C: Microconidia;D: Macroconidia;E-F: Clamidospore.
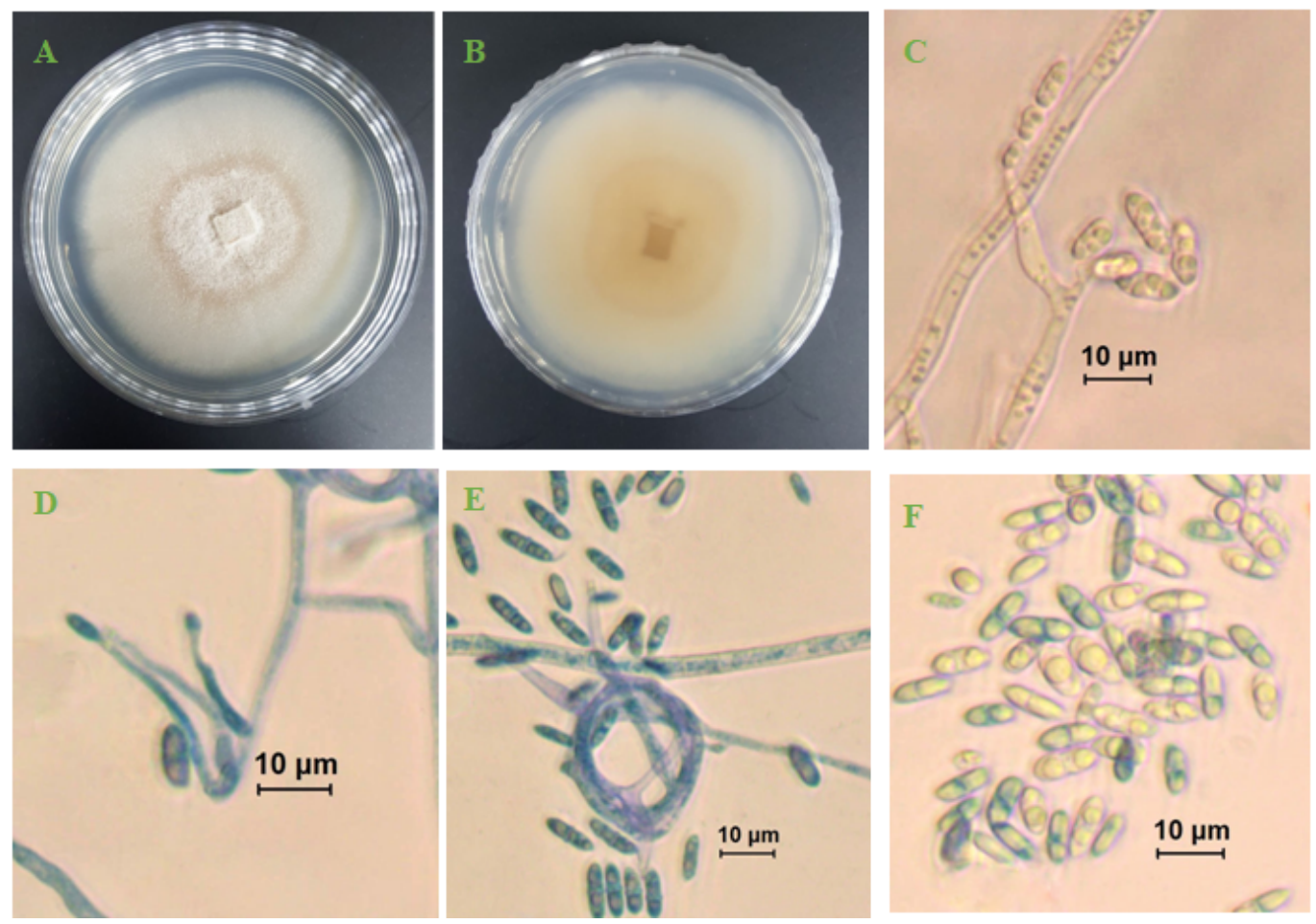

\section{Figure 6}

Morphological characteristics of Plectosphaerella cucumerina (isolate SJB271); A-B: Colony on PDA;C-D: Conidiophores and phialides;E: Hyphal coil and conidia;F: Conidia. 
$\mathbf{A}$

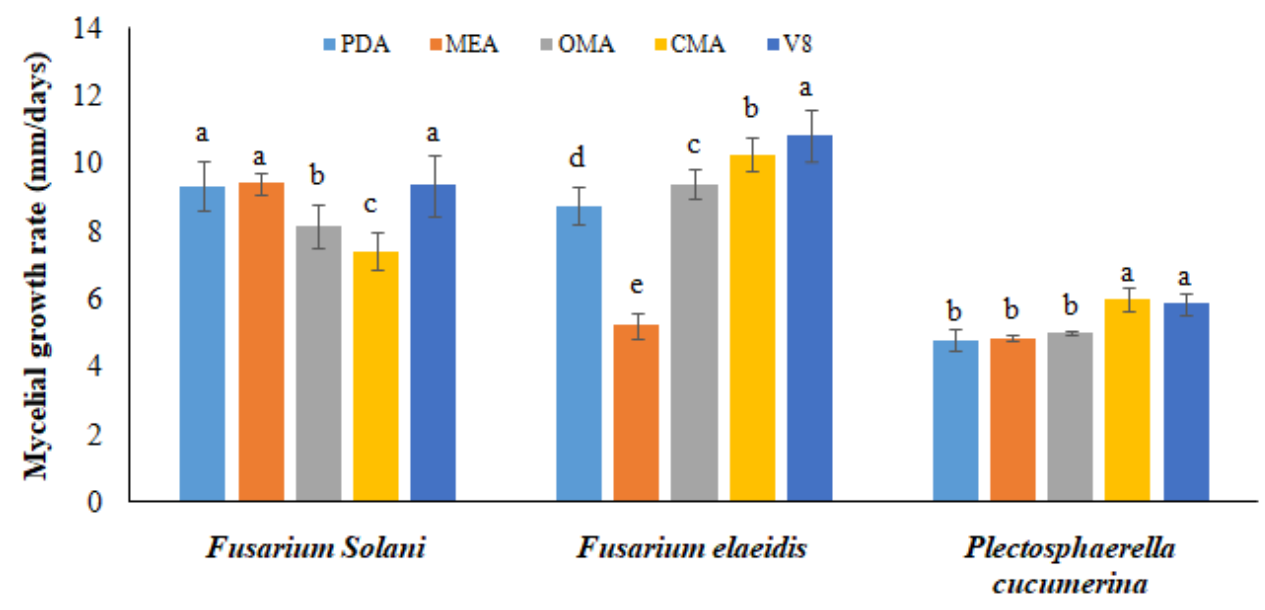

B

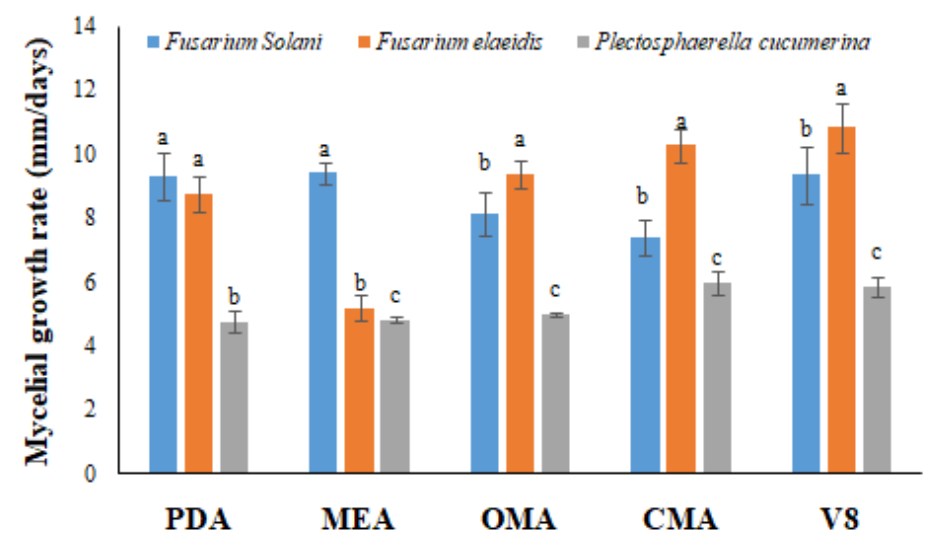

Figure 7

Effect of culture media on mycelial growth;A: Mycelial growth of different fungal species on some media;B: Mycelial growth of some fungal species on different media. 


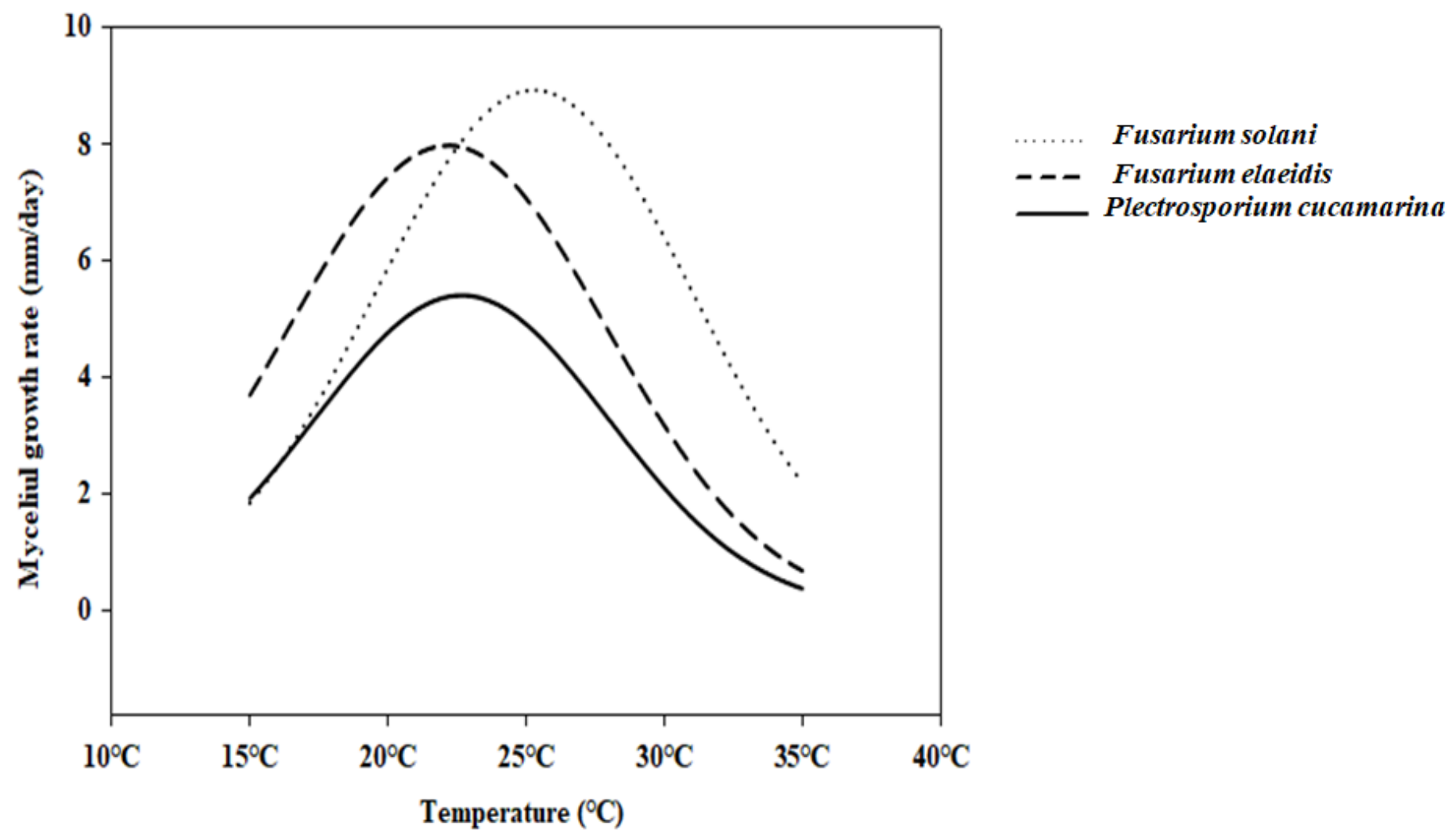

Figure 8

Mycelial growth rates of different fungal species at different temperatures. Gaussian process regression was used to estimate the optimum temperature for mycelial growth. 


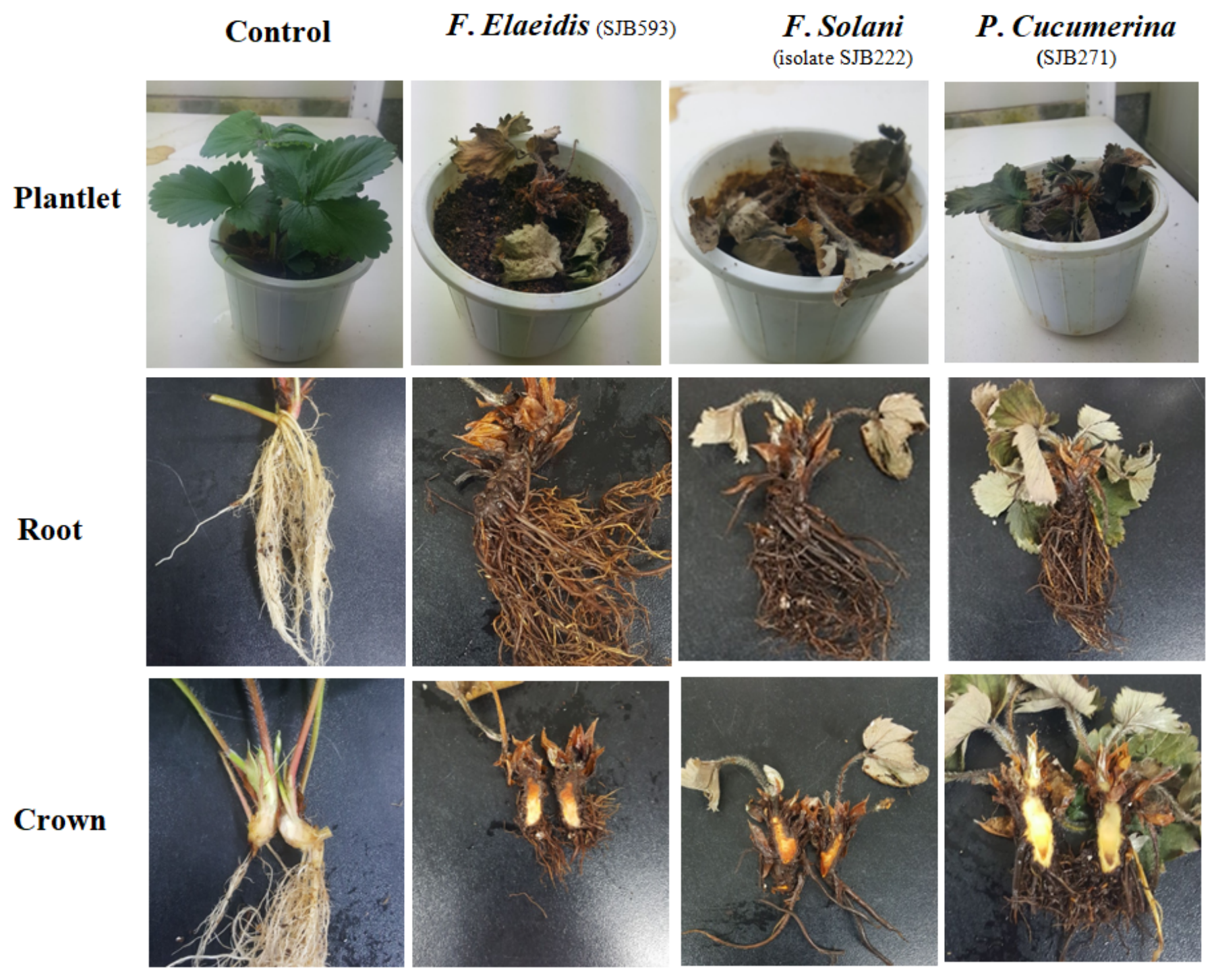

Figure 9

Symptoms showed by strawberry plantlets after inoculation with sterile water (control) and fungal speciesat $25^{\circ} \mathrm{C}$ and under $16 \mathrm{~h} / 8 \mathrm{~h}$ light/dark cycle. 